\title{
Design and Implement of Infrared Thermography Detection System Excited by Pulsed Flash Lamp
}

\author{
Zheng-wei YANG ${ }^{1}$, Qian Luo $^{2}$, Gan TIAN ${ }^{1,}$, Wei ZHANG ${ }^{1}$, Jie-tang ZHU1 \\ ${ }^{1} 602$ office, Xi’an Research Inst. of Hi-Tech, Xi’an, P.R. China, 710025. E-mail: yangzhengwei1136@163.com, *corre- \\ sponding author: tiantian_8282@sina.com, zhangweihuaiyu@163.com, zhujtown@sohu.com \\ ${ }^{2}$ The 41st Institute of Academy of China Aerospace Science and Technology Corporation National Key Laboratory of \\ Combustion, Flow and Thermo-structure, Xi’an, P.R. China, 710025. E-mail: lq03303706@163.com
}

Detection system of infrared thermography technology was designed, taking a non-refrigeration focal plane infrared camera and the pulse flash heating system with high energy as the core. Combining with the performance parameters and structure features of the hardware equipment, integrated control system was designed. Meantime, the cover and reflector for the detection system were fabricated, which improved the uniformity and the utilization rate of energy for the thermal excitation source of the flash lamp. Based on the Delphi program, control, acquisition, processing and analysis system for the infrared image sequence were developed. And defect identification software was also researched which could implement the quantitative calculation and analysis for the parameters of defect size, location, perimeter, area and depth. Finally, experiments for metal and composite with flat bottom defects were carried out by the use of the detection system proposed in this study. The results show that the detection system has the advantages of well controllable performance, convenient operation, perfect detection effect, powerful image processing functions, which can meet the testing demand for engineering application.

Keywords: Pulsed flash lamp, Infrared thermography, Design of the detection system

\section{Acknowledgement}

This study is supported by the National Natural Science Foundation of China (Grant No. 51305447) and the Natural Science Basic Research Plan in Shaanxi Province of China (Program No. 2013JM7021).

\section{References}

[1] ZHENG-WEI YANG, WEI ZHANG, CUI-QIN WU, GAN TIAN, YUAN-JIA SONG. (2010). Infrared Thermography applied to evaluate adhesive quality of missile motor shell (in Chinese). In: Chinese Journal of Scientific Instrument, Vol. 31, No. 12, pp. 2781-2787. Editorial Office of Chinese Journal of Scientific Instrument. Beijing.

[2] ZHENG-WEI YANG, WEI ZHANG, GAN TIAN, YUAN-JIA SONG, GUO-FENG JIN. (2011). Infrared thermography applied to detect debond defect in shell structure (in Chinese). In: Infrared and Laser Engineering, Vol. 40, No. 2, pp. 186-191.Tianjin.

[3] DILlENZ, A. WU, D. BREITRÜCK, AND G. BUSSE. (2006). Lock-in Thermography for Depth Resolved Defect Character-isation. In: Proceeding of 15th World conference on NDT.

[4] FAVRO L D, HAN X Y, ZHONG O Y , etal. (2000). Sonic IR Imaging of Cracks and Delaminations. In: Review of Scientific Instruments, No. 1, pp. 418-2421. AIP.

[5] XIAOYAN HAN, JIANPING LU. (2005). Sonic Infrared Imaging NDE. In: Proc. of SPIE (Masayoshi Tomizuka, (Ed.)), pp. 142-147. Bellingham, WA. Sheng-jie Tao, Zheng-wei Yang, Wei Zhang, Dong-dong Wang. (2014) Research on measurement of coating thickness based on thermal image time characteristic (in Chinese). In: Chinese Journal of Scientific Instrument, Vol. 35, No. 8, pp. 1810-1816.Tianjin.

[6] DOPJERA, D., MIČIAN, M. (2014). The Detection of Artificially Made Defects in Welded Joint with Ultrasonic defectoscopy, In: Manufacturing Technology, Vol. 14, No. 1, pp. 12-17. J. E. Purkyne University in Usti nad Labem.

[7] KOŇÁR, R., MIČIAN, M. (2014). The Detection of Artificially Made Defects in Welded Joint with Ultrasonic defectoscopy, In: Manufacturing Technology, Vol. 14, No. 1, pp. 52-47. J. E. Purkyne University in Usti nad Labem.

[8] DOPJERA, D., KOŇÁR, R., MIČIAN, M. (2014). Ultrasonic Testing of Girth Welded Joint with TOFD and Phased Array, In: Manufacturing Technology, Vol. 14, No. 3, pp. 281-286. J. E. Purkyne University in Usti nad Labem. 
[9] DAPENG CHEN, ZHI ZENG, CUNLIN ZHANG. (2012). Air-coupled ultrasonic infrared thermography for inspecting impact damage in CFRP composites, In: Chinese Optics Letters, N0. 1, pp. S10401. Chinese Laser Journal, Shanghai.

[10] ARCHAN VASUDEVAN. (2004). Application of Digital Infrared Thermography for Nondestructive Evaluation of Composite Bridge Components. West Virginia University: Master Thesis. American.

[11]MORTEZA SAFAI. (2006). Detection of Surface Cracks, Pits, and Scratches in Highly Reflective and Low Emissive Materials by Using a Laser Beam Trapping and Infrared Imaging, In: Proc. of SPIE (Jonathan J. Miles, (Ed.)), pp. 62051D.1-62051D.7.

[12] RENSHAW J, CHEN J C, HOLLAND S D. (2011). The sources of heat generation in virbrothermography. In: NDT \& E International, Vol. 44, No. 42, pp. 736-739. Elsevier Science Ltd. Holland.

[13]HENRIK BERGLIND, ALEXANDER, DILLENZ. (2003). Detecting glue deficiency in laminated wood - a thermography method comparison. In: NDT \& E International, Vol. 36, No. 6, pp. 395-399. 36(6): 395-399. Elsevier Science Ltd. Holland.

[14]SHU-FANG JIANG, XING-WANG GUO, JING-LING SHEN. (2005). Infrared thermal wave NDT on the disbonds of the heat insulated layer in solid propellant rocket motors. In: LASER \& INFRARED, Vol. 35, No. 8, pp. 584-586. Beijing

[15]XIAO-LIN YANG, TAO JANG, LI-CHUN FENG. (2009). Thermographic testing for impact damage of airplane composite. In: NDT, Vol. 31, No. 2, pp. 120-122. Shanghai. 